JOURNAL OF

HORTICULTURAL

SCIENCES
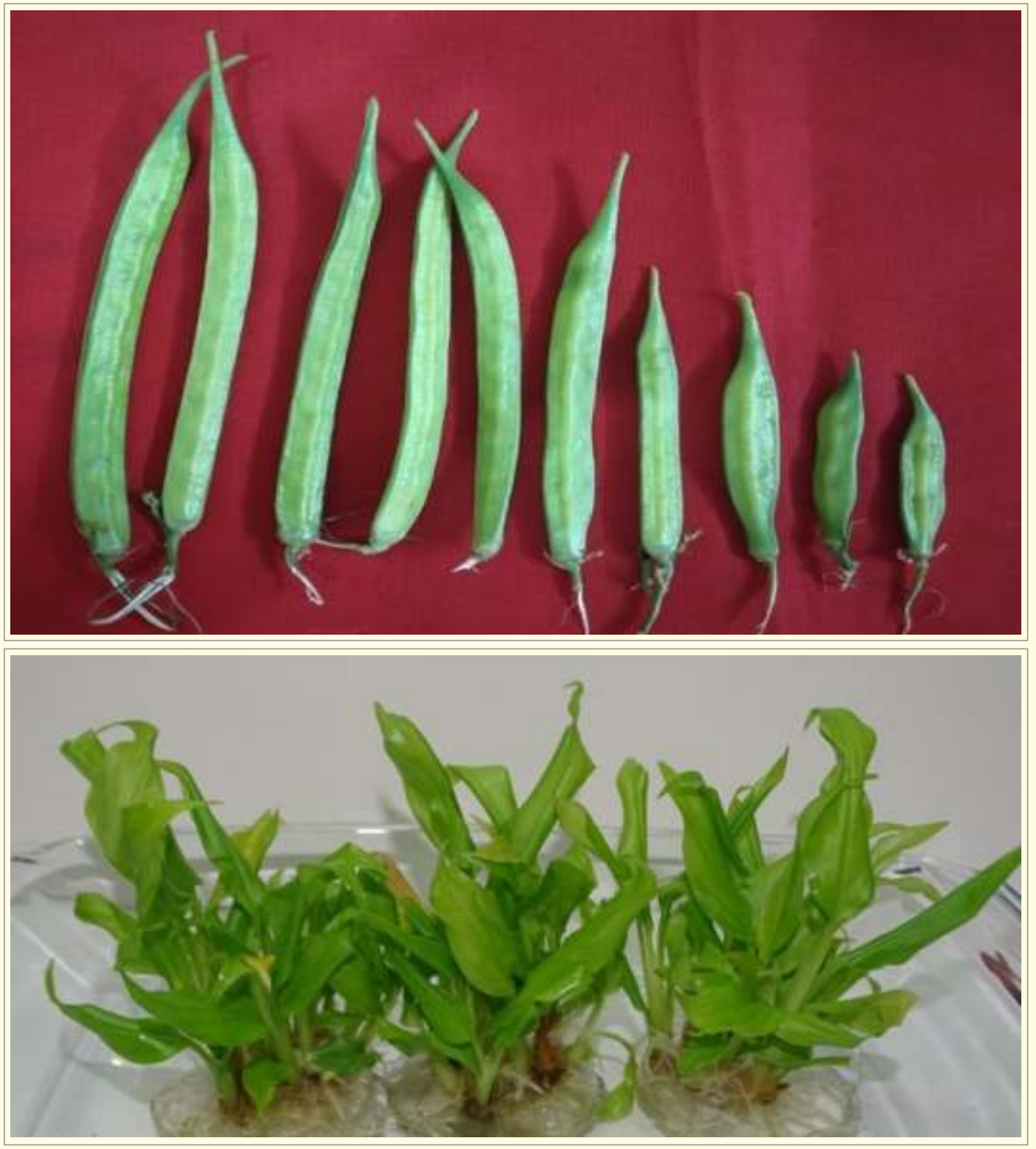

Society for Promotion of Horticulture

ICAR - Indian Institute of Horticultural Research, Bengaluru - 560089 


\section{JOURNAL OF HORTICULTURAL SCIENCES}

\section{ONTENTS}

\section{In this Issue}

\section{Review}

Moringa (Moringa oleifera L.): An underutilized and traditionally valued

tree holding remarkable potential

Jattan M., Kumari N., Raj Kumar, Kumar A., Rani B., Phogat D.S.,

Kumar, S. and Kumar, P.

\section{Original Research in Papers}

Characterization and evaluation of mountain sweet thorn

(Flacourtia montana J. Grah) collections

Tripathi P.C., Ganeshan S., Radhika V. and Shetti D.L.

Optimization of methodology for the extraction of polyphenolic compounds

with antioxidant potential and á-glucosidase inhibitory activity from jamun

(Syzygium cumini L.) seeds

Arivalagan M., Priyanka D.R. and Rekha A.

Genetic variability studies in amaranthus (Amaranthus spp.)

Agadi A.H., Kolakar S., Lakshmana D., Nadukeri S. and Hanumanthappa M.

Morpho-physiological parameters associated with chlorosis resistance to

iron deficiency and their effect on yield and related attributes in potato

(Solanum tuberosum L.)

Challam C., Dutt S., Sharma J., Raveendran M. and Sudhakar D.

Responses of different Okra (Abelmoschus esculentus) cultivars to water

deficit conditions

Ayub Q., Khan S.M., Hussain I., Naveed K., Ali S., Mehmood A., Khan M.J., Haq N.U., Shehzad Q.

Induced variability for yield and its attributing traits in cluster bean

[Cyamopsis tetragonoloba (L. ) Taub] through gamma irradiation

Lavanya H.N., Mishra S., Sood M., Aghora T.S., Anjanappa M., Rao V.K. and Reddy A.B.

In vitro multiplication protocol for Curcuma mangga : Studies on carbon,

Waman A.A., Bohra P., Karthika Devi R. and Pixy J. 
Effect of fungicide and essential oils amended wax coating on quality and shelf life of sweet orange (Citrus sinensis Osbeck)

Bhandari M., Bhandari N. and Dhital M.

Post-harvest quality and quantification of betalains, phenolic compounds and antioxidant activity in fruits of three cultivars of prickly pear

(Opuntia ficus-indica L. Mill)

Gonzalez F.P.H., Saucedo V.C., Guerra R.D., Suarez E.J., Soto H.R.M. Lopez J.A.,

Garcia C.E. and Hernandez R.G.

Soil microbial community dynamics as influenced by integrated nutrient management practices in sweet basil (Ocimum basilicum L.) cultivation Baraa AL-Mansour and D. Kalaivanan

Effect of spectral manipulation and seasonal variations on cut foliage production and quality of Philodendron (Philodendron 'Xanadu')

Sujatha A. Nair, Laxman R.H. and Sangama

\section{Short Communications}

Studies on mutagenic sensitivity of seeds of pummelo (Citrus maxima Merr.)

Sankaran M., Kalaivanan D. and Sunil Gowda D.C.

Isolation and characterization of microsatellite markers from

Garcinia indica and cross species amplification

Ravishankar K.V., Vasudeva R., Hemanth B., Nischita P., Sthapit B.R.,

Parthasarathy V.A. and Rao V.R. 
Original Research Paper

\title{
In vitro multiplication protocol for Curcuma mangga : Studies on carbon, cytokinin source and explant size
}

\author{
Waman A.A., Bohra P. , Karthika Devi R. and Pixy J. \\ ICAR - Central Island Agricultural Research Institute, \\ Port Blair, Andaman and Nicobar Islands, India \\ *Corresponding author e-mail : pooja.bohra@icar.gov.in
}

\begin{abstract}
Mango ginger (Curcuma mangga Valeton \& Zijp.) is an underutilized rhizomatous species that has been valued in the tropical Asian countries as a source of vegetable, spice, salad, medicine and essential oil. This species is hardy and requires less care for obtaining good yields. Rhizomes are the commonly used propagules for the species, which are also the economic part of the crop. Huge quantity of seed rhizomes is required to promote this crop in larger area. Efficient in vitro multiplication protocol is one of the options to meet the planting material requirement. Effects of carbon source (glucose, fructose and sucrose) and concentration ( 1 and 3\%, w/v), cytokinins (BAP and meta topolin) and concentration (1 mg/ $\mathrm{L}$ and $2 \mathrm{mg} / \mathrm{L}$ ), size of explants (one/ two/ three bud) and IBA treatment $(0,250,500$ and $1,000 \mathrm{mg} / \mathrm{L}$ ) for concurrent ex vitro rooting cum hardening were studied. Results revealed that for facilitating efficient multiplication, medium should be supplemented with glucose $(3 \%)$ as carbon source and meta topolin $(1 \mathrm{mg} / \mathrm{L})$ as cytokinin. Two-bud explant should be used for subculture as it promoted superior shoot proliferation. Concurrent ex vitro rooting cum hardening was possible even without auxin treatment. The present protocol could be useful for large scale production of quality planting material of this underexploited tropical species.
\end{abstract}

Keywords: Ex vitro rooting, Glucose, Hardening, Inoculum size, Mango ginger and Tropical

\section{INTRODUCTION}

Curcuma mangga Valeton \& Van Zijp. is an important species of Zingiberaceae family, which is found distributed in Asian countries including Java, India, Thailand, Malaysia and Indonesia (Sirirugsa et al., 2007; Leong-Škorničková et al., 2010; Singh, 2017). In most of the native regions, young shoots and rhizomes of this underutilized species are used as vegetable, salad or medicine. It is known to be a source of curcumin, a key component in drug industries due to its numerous uses (Aggarwal et al., 2007). Curcumin is found in all rhizome parts including mother, primary and secondary rhizomes in the range of 0.34 to $0.45 \%$ (Waman et al., 2018). Studies suggested that the species possesses antioxidant, anticancer and anti-inflammatory activities (Liu and Nair, 2012; Malek et al., 2011). Recently, a cream formulation containing $C$. mangga was found to have wound healing and anti- inflammatory activities (Suthasinee and Supinya, 2019). Further, it has been found to be a source of essential oil, which contains $\beta$-myrcene (52.4 to $65.3 \%$ ) as dominant compound (Wahab et al., 2011, Waman et al., 2018). Considering raw mango like aroma of rhizomes, the species has good scope for use as a flavouring agent in processing industries as well.

Mango ginger, like other rhizomatous species, is propagated by using rhizome pieces. During earlier studies, seed rhizomes (15 to $25 \mathrm{~g}$ size) have been recommended for obtaining produce suitable for fragrance, pharmaceutical and value addition industries (Waman et al., 2018). However, mango ginger is generally planted at a closer spacing of 25 to $30 \mathrm{~cm}$, thereby requiring higher quantities of planting material. Micropropagation is an efficient means for large scale production of plantlets. 
Earlier studies on in vitro culture in the species have primarily dealt with optimization of plant growth regulators for direct shoot regeneration and somatic embryogenesis (Hutami and Purnamaningsih, 2003; Raihana et al., 2011; Pikulthong et al., 2016). However, a number of factors are known to determine the ultimate success of a micropropagation protocol (Waman and Bohra, 2018). Carbon sources are generally added in the culture medium for providing necessary energy and to act as an osmoticum (Lipavska and Konradova, 2004). As both kind and concentration of carbon source influence in vitro culture response, these aspects were studied in present investigation. Further, new sources of cytokinins such as meta topolins have been found to be superior in several species (Escalona et al., 2003; Bairu et al., 2008; Woztania, 2010) and hence, its efficacy was tested in C. mangga. Optimization of explant size is required for obtaining maximum shoots per unit inputs (Elboullani et al., 2017) and hence, was also studied here. Process of concurrent ex vitro rooting cum hardening (CEVRH, method in which in vitro derived shoots are subjected to rooting and hardening simultaneously) has been found to be superior method than in vitro rooting and hardening in various species (Bohra et al., 2016). Hence, the present investigation was undertaken for standardization of carbon source, cytokinin, size of inoculum and CEVRH for in vitro culture of C. mangga.

\section{MATERIALS AND METHODS}

Present investigation was carried out in the Plant Tissue Culture Laboratory, Division of Horticulture and Forestry, ICAR-Central Island Agricultural Research Institute, Port Blair, Andaman and Nicobar Islands, India during 2018-19. Chemicals including salts of MS medium, plant growth regulators, carbon sources, gelling agents etc. were procured from $\mathrm{M} / \mathrm{s}$. HiMedia Laboratories, Mumbai, India. Borosilicate culture bottles of $200 \mathrm{ml}$ capacity with polypropylene screw caps were used for culture incubation.

\section{Media preparation and culture incubation}

For all the experiments, MS medium was used and other inputs were added as per the experiment. $\mathrm{pH}$ of the medium was adjusted to 5.7 using digital $\mathrm{pH}$ meter (Hanna, HI2211). Medium was gelled using Clerigar $(5 \mathrm{~g} / \mathrm{L})$ and $30 \mathrm{ml}$ of it was dispensed into each culture bottle prior to sterilizing in autoclave
(Optics Technology, Delhi) at $121{ }^{\circ} \mathrm{C}$ for $15 \mathrm{~min}$. Culture bottles were wrapped with cling film and were incubated at $24{ }^{\circ} \mathrm{C}$ with photoperiod of 16:8 (light: dark) cycle. For maintaining photoperiod, $40 \mathrm{~W}$ fluorescent lights (Crompton Greaves, Mumbai) were used.

\section{Collection of explants and aseptic culture establishment}

Growing shoots of $C$. mangga (IC-0628643) were collected from experimental fields of the Institute. Shoots were separated after washing of clumps in running tap water to remove adhering soil. Rhizome blocks containing shoot tips were excised from the clumps and used for establishing aseptic cultures. For this, excised tissue blocks were soaked in $0.2 \%$ carbendazim (Bavistin) and streptocyclin sulphate $(200 \mathrm{mg} / \mathrm{L})$ for $20 \mathrm{~min}$. It was followed by removal of thin layer of tissues from the blocks. In laminar air flow, the excised explants were washed with sterile deionized water, followed by surface sterilization using $0.1 \%$ mercuric chloride (12 min.). Such explants were rinsed thoroughly for four times with sterilized deionized water to remove traces of mercuric chloride. Explants were initiated onto basal Murashige and Skoog's (MS) medium supplemented with ascorbic acid $(50 \mathrm{mg} / \mathrm{L})$.

\section{Effect of carbon sources and their concentrations on shoot multiplication}

Effect of three types of carbon sources (glucose, fructose and sucrose) at 1 and $3 \%$ concentration was studied on culture multiplication. Medium was supplemented with $1 \mathrm{mg} / \mathrm{L}$ BAP and $0.2 \mathrm{mg} / \mathrm{L}$ NAA. Cultures obtained after first subculture were used for the experiment. Besides culture growth parameters, chlorophyll content in leaves of micro-shoots obtained from various treatments was determined by procedure described earlier (Lichtenthaler and Wellburn 1983).

\section{Effect of cytokinins on shoot multiplication}

Effect of two cytokinin viz. 6- benzylamino purine (BAP) and meta topolin $(m \mathrm{~T})$ at $1 \mathrm{mg} / \mathrm{L}$ and $2 \mathrm{mg} / \mathrm{L}$ was studied during subculture 4 and 5. Growth regulator free MS medium was used as control. During subculture 6 , both levels of $m \mathrm{~T}$ were compared with MS basal medium. Media also contained $0.2 \mathrm{mg} / \mathrm{L}$ naphthalene acetic acid (NAA) and glucose $(3 \%)$ as carbon source. Experiment was 
laid in CRD with six replications each during subculture 4 and 5 and nine replications during subculture 6 .

\section{Effect of size of explant on culture multiplication}

Effect of one, two and three bud explant was studied on culture multiplication. MS medium supplemented with $m \mathrm{~T}(2 \mathrm{mg} / \mathrm{L})+\mathrm{NAA}(0.2 \mathrm{mg} / \mathrm{L})+$ glucose $(3 \%)$ was used for the experiment. Experiment was laid in CRD with ten replications each.

\section{Effect of auxin dipping on CEVRH}

Concurrent ex vitro rooting cum hardening was studied in which effect of three concentrations of indole-3- butyric acid (IBA, 250, 500 and 1,000 mg/ L) was compared with de-ionized water as control. Micro-shoots of $c a .3 \mathrm{~cm}$ were excised and washed with water to remove adhering agar. Basal parts of the micro-shoots were dipped in the solution (30 s) and planted in cups of $200 \mathrm{ml}$ capacity filled with coir pith as a substrate. Plantlets were covered with polythene bags to maintain humidity during hardening. Experiment was laid in CRD. Survival and growth parameters were recorded after 7 weeks of transplanting. For establishment, two replications of ten plants each were used, while for growth observations, ten plants were used.

\section{Experimental design, data collection and statistical analysis}

All the experiments were laid out in completely randomized design (CRD). All the values were presented as mean \pm standard error of mean. Data collected from all the experiments was subjected to analysis of variance using Web Agri Statistical
Package (WASP v. 2.0, ICAR- CCARI, Goa, India). Mean separation was done using least significant difference.

\section{RESULTS AND DISCUSSION}

\section{Effect of carbon sources and their concentrations}

Influence of three carbon sources at two levels was studied on in vitro shoot multiplication in mango ginger (Table 1), which revealed significant differences among the treatments. Sucrose is mainly employed as a source of energy in culture medium. However, kind and concentration vary depending upon the species (Sharmin et al., 2013). During the present investigation, glucose $(3 \%)$ was found to support significantly superior multiplication (6.3 shoots/ culture). Though higher number of shoots was produced in media supplemented with 3\% concentration than those with $1 \%$ sugars; except for glucose, none of the treatments were statistically significant. Positive effects of glucose on culture multiplication have been reported in C. longa (Salvi et al., 2001) and banana (Bohra et al., 2016).

Alteration of carbon source or its content had no influence on number of leaves per micro-shoot (3.8 to 5.8$)$ and mean shoot length $(3.6 \mathrm{~cm}$ to $5.5 \mathrm{~cm})$. Interestingly, despite producing highest number of shoots, medium supplemented with glucose $(3 \%)$ could not improve leaf production and shoot length. It was probably due to utilization of energy for shoot bud proliferation rather than for leaf production. Previous studies on banana have also suggested significant role of carbon source (sucrose/dextrose/ fructose, when used alone) on shoot multiplication,

Table 1: Effect of carbon source and their concentration on shoot multiplication in $C$. mangga.

\begin{tabular}{|l|c|c|c|}
\hline Carbon source & No. of shoots/ explant & No. of leaves/ shoot & Mean shoot length (cm) \\
\hline Fructose (1\%) & $1.8 \pm 0.48 \mathrm{~b}$ & $5.8 \pm 0.25 \mathrm{a}$ & $3.8 \pm 0.90 \mathrm{a}$ \\
\hline Fructose (3\%) & $3.0 \pm 0.58 \mathrm{~b}$ & $5.0 \pm 0.34 \mathrm{a}$ & $4.8 \pm 0.38 \mathrm{a}$ \\
\hline Glucose (1\%) & $2.3 \pm 0.63 \mathrm{~b}$ & $4.4 \pm 1.20 \mathrm{a}$ & $3.6 \pm 0.94 \mathrm{a}$ \\
\hline Glucose (3\%) & $6.3 \pm 1.25 \mathrm{a}$ & $3.8 \pm 0.25 \mathrm{a}$ & $4.5 \pm 0.39 \mathrm{a}$ \\
\hline Sucrose (1\%) & $2.0 \pm 0.00 \mathrm{~b}$ & $5.0 \pm 0.20 \mathrm{a}$ & $4.0 \pm 0.27 \mathrm{a}$ \\
\hline Sucrose (3\%) & $2.8 \pm 0.25 \mathrm{~b}$ & $4.6 \pm 0.31 \mathrm{a}$ & $5.5 \pm 0.40 \mathrm{a}$ \\
\hline
\end{tabular}

Values presented as mean \pm SE. Values followed by similar alphabet in a column do not differ significantly at $5 \%$ level of significance using least significant difference 
while there was no significant difference in mean shoot length (Madhulatha et al., 2006).

Differences in chlorophyll content in micro-shoots were influenced by treatments (Fig. 1). Highest values of photosynthetic pigments viz. Chl a $(1.77 \mathrm{mg} / \mathrm{g}), \mathrm{Chl}$ b $(0.54 \mathrm{mg} / \mathrm{g})$ and total chlorophyll content $(2.31 \mathrm{mg} /$ g) were reported from shoots cultured on medium containing 3\% glucose. This means, treatment $\mathrm{D}_{3}$ not only produced a greater number of shoots, but also had higher accumulation of photosynthetic pigments in them. Such improvement in chlorophyll concentration with increment in quantity of carbon source in the medium has been reported by Capellades et al. (1991) in rose. On the contrary, the lowest values for photosynthetic pigments $(0.58 \mathrm{mg} / \mathrm{g}, 0.15$ $\mathrm{mg} / \mathrm{g}$ and $0.73 \mathrm{mg} / \mathrm{g}$ ) were observed in shoots derived from cultures grown on $\mathrm{F}_{3}$. This suggested specificity

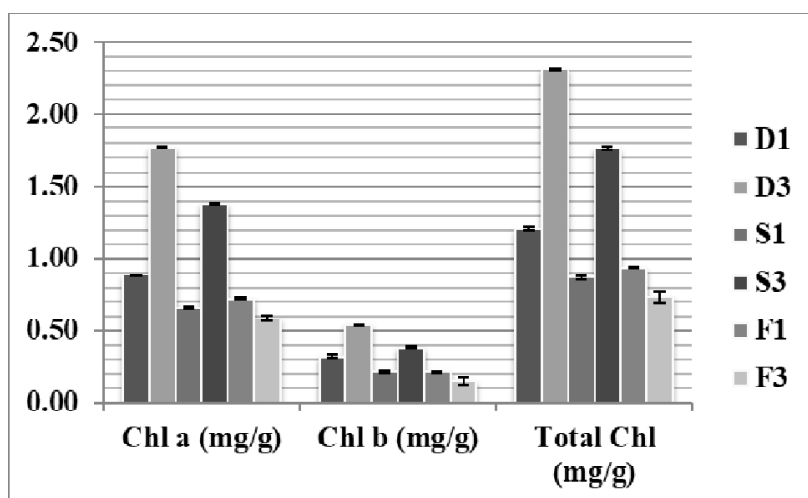

of carbon source required for C. mangga in the present study.

Fig. 1: Chlorophyll components $(\mathrm{mg} / \mathrm{g})$ in leaves of micro-shoots cultured on media supplemented with different carbon sources $\left(\mathrm{D}_{1}\right.$ : Glucose $10 \mathrm{gL}^{-} ; \mathrm{D}_{3}$ : Glucose $30 \mathrm{gL}^{-1} ; \mathrm{S}_{1}$ : Sucrose $10 \mathrm{gL}^{-1} ; \mathrm{S}_{3}$ : Sucrose $30 \mathrm{gL}-$

$$
\begin{aligned}
& \left.{ }^{1} ; \mathrm{F}_{1}: \text { Fructose } 10 \mathrm{gL}-^{1} ; \mathrm{F}_{3}: \text { Fructose } 30 \mathrm{gL}^{-1}\right) . \\
& \text { Values are expressed as mean } \pm \mathrm{SE} .
\end{aligned}
$$

\section{Effect of cytokinins on shoot multiplication}

Cytokinins are added in culture medium to facilitate shoot proliferation and its requirement needs to be standardized for each species. In present study, performance of BAP and $m \mathrm{~T}$ was tested in comparison with growth regulator free medium as control during fourth and fifth culture cycles. Even without cytokinins, culture multiplication of 4.0 and 8.2 shoots/ inoculum was possible (Table 2). However, Raihana et al. (2011) reported mere 1.2 to 2.3 shoots per explant in growth regulator free medium. This variation could be attributed to differences in the genotypes used in both studies, probably indicating higher concentration of endogenous cytokinins in genotype used in present study.

Though, addition of BAP supported shoot multiplication up to $7.0(1 \mathrm{mg} / \mathrm{L})$ and $7.7(2 \mathrm{mg} / \mathrm{L})$ shoots/ culture during fourth subculture, the cytokinin was not effective in inducing multiple shoot buds in subsequent cycle and values remained on par with MS basal medium (Table 2). Similar observations have been reported by Raihana et al. (2011) in $C$. mangga, who observed non-significant differences among cultures grown on basal medium and those grown on media supplemented with up to $11 \mathrm{mg} / \mathrm{L}$ BAP. Hence, from findings of both present and earlier report, considering the low efficacy of BAP, it should be avoided for obtaining mass multiplication in $C$. mangga. Similarly, Wojtania (2011) had encountered similar conditions in which BAP did not improve,

\begin{tabular}{|c|c|c|c|c|}
\hline \multirow[t]{2}{*}{ Treatment } & \multicolumn{2}{|c|}{ No. of shoots/ inoculum } & \multicolumn{2}{|c|}{ No. of leaves/ shoot } \\
\hline & SC 4 & SC 5 & SC 4 & SC 5 \\
\hline Basal & $4.0 \pm 0.68 \mathrm{~b}$ & $8.2 \pm 1.30 \mathrm{~b}$ & $2.8 \pm 0.37 \mathrm{a}$ & $4.1 \pm 0.18 \mathrm{a}$ \\
\hline$m \mathrm{~T}(1 \mathrm{mg} / \mathrm{l})$ & $8.0 \pm 0.73 \mathrm{a}$ & $13.3 \pm 0.84 \mathrm{a}$ & $0.8 \pm 0.11 \mathrm{c}$ & $2.4 \pm 0.31 \mathrm{~b}$ \\
\hline$m \mathrm{~T}(2 \mathrm{mg} / \mathrm{l})$ & $9.3 \pm 1.05 \mathrm{a}$ & $15.2 \pm 1.56 \mathrm{a}$ & $1.0 \pm 0.11 \mathrm{c}$ & $2.4 \pm 0.16 b$ \\
\hline BAP $(1 \mathrm{mg} / \mathrm{l})$ & $7.0 \pm 0.45 \mathrm{a}$ & $7.0 \pm 0.45 \mathrm{~b}$ & $2.1 \pm 0.18 \mathrm{~b}$ & $4.0 \pm 0.29 \mathrm{a}$ \\
\hline $\mathrm{BAP}(2 \mathrm{mg} / \mathrm{l})$ & $7.7 \pm 1.15 \mathrm{a}$ & $9.2 \pm 1.40 \mathrm{~b}$ & $2.0 \pm 0.25 \mathrm{~b}$ & $3.9 \pm 0.35 \mathrm{a}$ \\
\hline
\end{tabular}

Table 2: Effect of cytokinins on shoot multiplication in $C$. mangga during subculture

$\mathrm{SC}-\mathrm{Sub}$ culture, Values presented as mean $\pm \mathrm{SE}$. Values followed by similar alphabet in a column do not differ significantly at $5 \%$ level of significance using least significant difference 
Table 3: Effect of meta topolin on shoot multiplication in Curcuma mangga during sub-culture 6

\begin{tabular}{|l|c|c|c|}
\hline Treatment & No. of shoots/ inoculum & No. of leaves/ shoot & Mean shoot length (cm) \\
\hline Basal & $7.9 \pm 1.05 \mathrm{~b}$ & $4.5 \pm 0.38 \mathrm{a}$ & $8.1 \pm 0.31 \mathrm{a}$ \\
\hline$m \mathrm{~T}(1 \mathrm{mg} / \mathrm{l})$ & $11.9 \pm 0.79 \mathrm{a}$ & $3.9 \pm 0.26 \mathrm{ab}$ & $6.4 \pm 0.56 \mathrm{~b}$ \\
\hline$m \mathrm{~T}(2 \mathrm{mg} / \mathrm{l})$ & $13.7 \pm 1.39 \mathrm{a}$ & $3.4 \pm 0.14 \mathrm{~b}$ & $5.9 \pm 0.11 \mathrm{~b}$ \\
\hline
\end{tabular}

Values presented as mean \pm SE. Values followed by similar alphabet in a column do not differ significantly at $5 \%$ level of significance using least significant difference

rather hampered the shoot proliferation process in Pelargonium hybrids.

Meta topolin was found to be highly efficient cytokinin in the present study. As high as 9.6 (subculture 4) and 15.2 (subculture 5) shoots/ inoculum were reported in cultures grown on medium supplemented with 2 $\mathrm{mg} / \mathrm{L} m \mathrm{~T}$. These values remained statistically similar with shoot multiplication observed on medium supplemented with $1 \mathrm{mg} / \mathrm{L} m \mathrm{~T}$. Present findings suggested the efficacy of $m \mathrm{~T}$ in mango ginger even at low concentrations. The results are in conformity with studies in Pelargonium hybrids, wherein $m \mathrm{~T}$ was found to be more promising cytokinin whereas BAP did not show positive signs on multiplication (Wojtania 2011). Interestingly, number of leaves/ shoots showed reducing trend as shoot multiplication increased. This was more prominent in case of $m \mathrm{~T}$ as these treatments induced higher bud proliferation.

During subculture 6 also, similar trend was maintained in which 13.7 and 11.9 shoots/ culture were obtained in medium supplemented with $2 \mathrm{mg} /$ $\mathrm{L}$ and $1 \mathrm{mg} / \mathrm{L} m \mathrm{~T}$ as against 7.9 shoots/culture in MS basal medium (Table 3). Superiority of $m \mathrm{~T}$ in long term culture has previously been reported (Wojtania 2011), thereby suggesting the superiority of $m \mathrm{~T}$ observed in present study. About 4.5 leaves/ shoot were produced in control, which remained on par with shoots obtained from $1 \mathrm{mg} / \mathrm{L}$ of $m \mathrm{~T}$ (3.9 leaves/ shoot). Longest shoots $(8.1 \mathrm{~cm})$ were noticed in cultures grown onto basal medium and increase in $m \mathrm{~T}$ concentration resulted in decrease in shoot length to $6.4 \mathrm{~cm}$ and $5.9 \mathrm{~cm}$.

\section{Effect of explant size on culture multiplication}

Optimum explant density is one of the key determinants for success of a micropropagation protocol. In the present study, culture multiplication improved from 7.1 (one bud) to 12.9 (two bud) and
12.8 (three bud) (Fig. 2 and 3). As there was no significant difference between two and three bud explant, it is recommended to use two bud inoculum as it would reduce the explant requirement without compromising the multiplication ratio. Influence of explant density on culture multiplication has been reported in turmeric and globe artichoke (El-Hawaz et al., 2015; El Boullani et al., 2017).

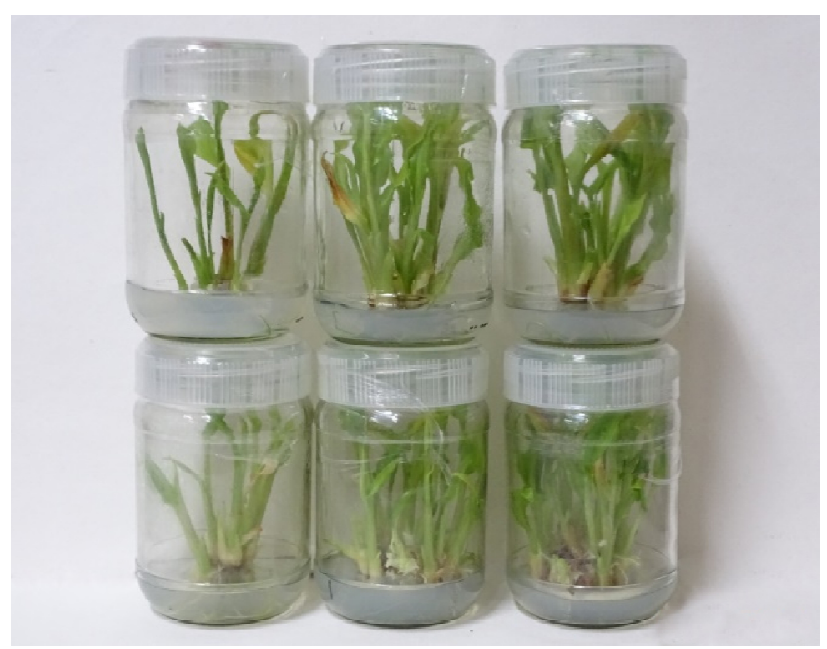

Fig. 2: Effect of inoculum density on in vitro culture multiplication in C. mangga;

(one bud, two bud and three bud - from left to right)

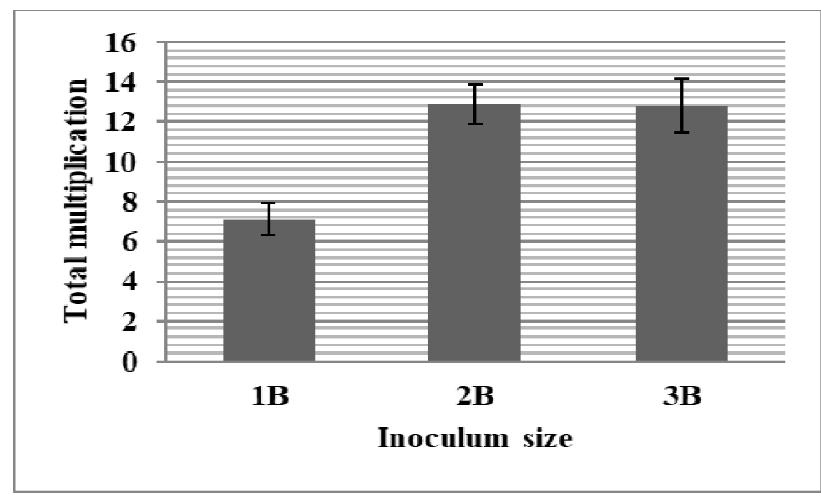

Fig. 3: Effect of explant size (1B: one bud; 2B: two bud and 3B: three bud) on culture multiplication in $C$. mangga. Values are expressed as mean $\pm \mathrm{SE}$. 


\section{Effect of auxin dipping on CEVRH}

Single step ex vitro rooting cum hardening has been considered as an efficient method to reduce time, labour and other operational costs (Ranaweera et al., 2013). This is particularly relevant in cases wherein planting material requirement per unit area is higher as in case of present species. During present study, root induction and hardening was possible without external auxin application (Fig. 4). In fact, auxin dip had adverse effect on these parameters. All the microshoots treated with deionized water (control) showed $100 \%$ establishment and rooting percentage got reduced to $60 \%$ at the highest $(1,000 \mathrm{mg} / \mathrm{L})$ concentration of IBA (Fig. 5). Being a rhizomatous species, each micro-shoot carried a small part of rhizome at the base and when transferred to the substrate ex vitro, it might have given the stimulus for root induction as seen in case of rhizome sett grown plants.
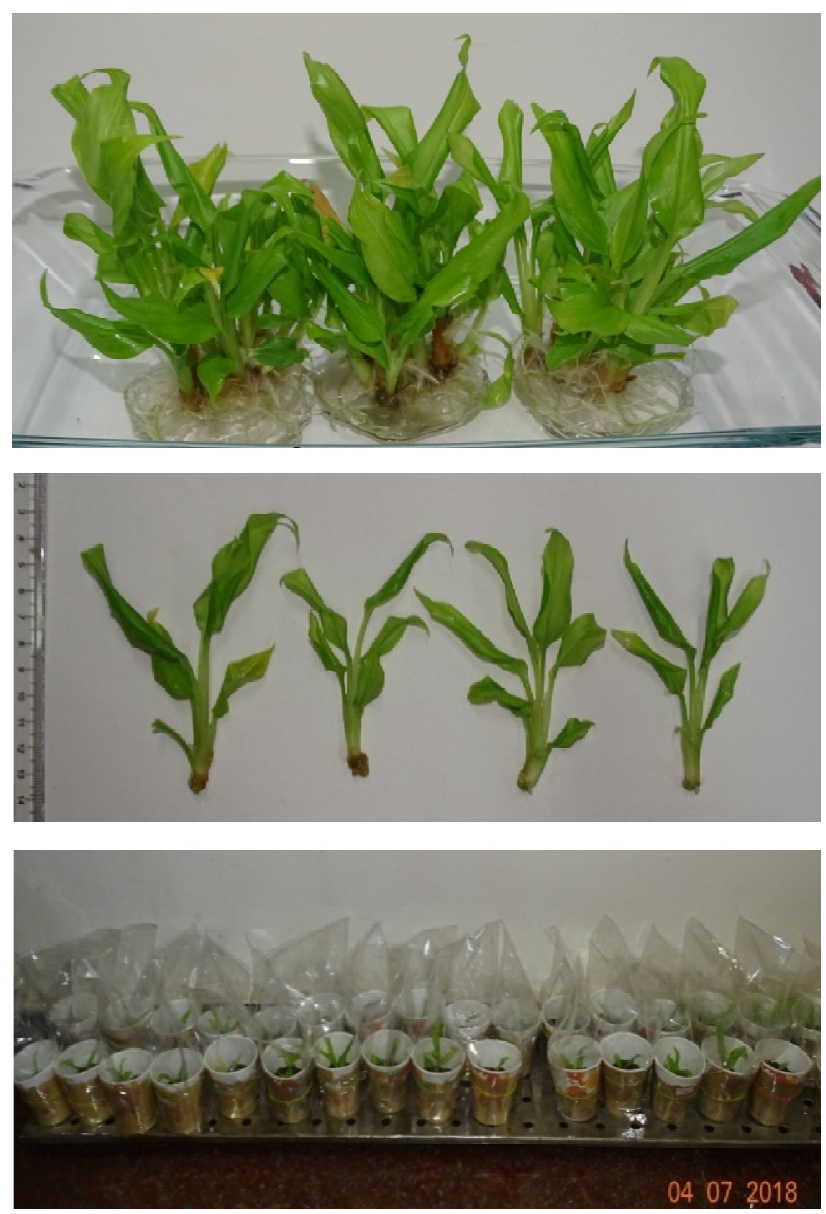

Fig. 4: Concurrent ex vitro rooting cum hardening (CEVRH): multiplied cultures (a), isolated micro-shoots (b) and micro-shoots planted in cups for hardening

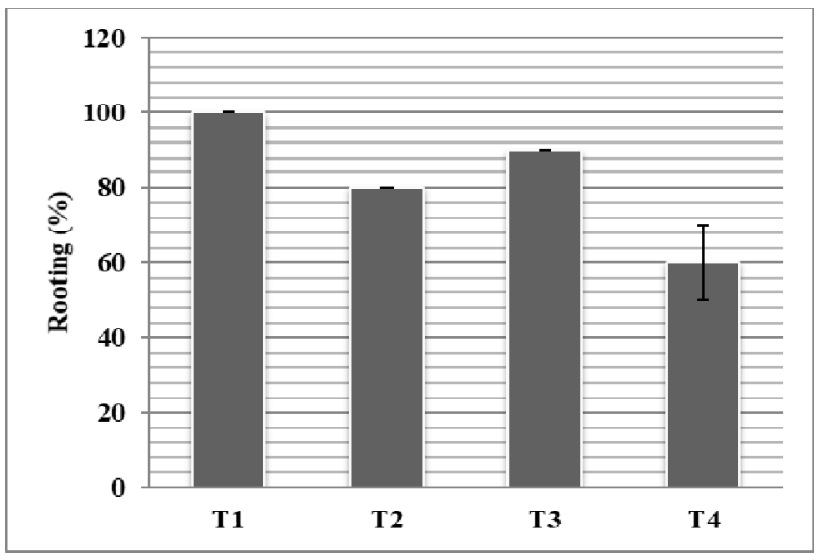

Fig. 5: Root induction percentage as influenced by auxin (IBA) dipping treatments $\left(\mathrm{T}_{1}: 0 \mathrm{mgL}^{-1} ; \mathrm{T}_{2}: 250 \mathrm{mgL}^{-1} ; \mathrm{T}_{3}\right.$ :

$500 \mathrm{mgL}^{-1} ; \mathrm{T}_{4}: 1000 \mathrm{mgL}^{-1}$ ) during concurrent ex vitro rooting cum hardening (CEVRH) in C. mangga

Growth parameters as influenced by CEVRH have been presented in Table 4. Values amongst the treatments varied between $4.0 \pm 0.46 \mathrm{~cm}$ and $5.0 \pm$ $0.70 \mathrm{~cm}$ (shoot length), $0.50 \pm 0.03 \mathrm{~cm}$ and $0.50 \pm$ $0.05 \mathrm{~cm}$ (collar thickness), $4.0 \pm 0.57$ and $4.9 \pm 0.55$ (number of primary roots), $2.6 \pm 0.21 \mathrm{~cm}$ and $3.2 \pm$ $0.45 \mathrm{~cm}$ (mean root length), $5.2 \pm 0.70$ and $5.5 \pm 0.71$ (number of leaves per plantlet). As none of the treatments could improve the plant growth over control, it could be recommended to use in vitro grown micro-shoots for ex vitro rooting and hardening without any auxin dip. Hardened plants were transplanted in pots and all the plants grew normally.

\section{CONCLUSION}

In the present study, an efficient micropropagation protocol was developed for C. mangga. Various factors studied showed profound influence on the in vitro multiplication of the species. Use of MS medium supplemented with glucose $(3 \%)$ as carbon source and meta topolin $(1 \mathrm{mg} / \mathrm{L})$ as cytokinin was recommended to promote superior shoot proliferation. Single step ex vitro rooting cum hardening was successful even in the absence of auxin treatment.

\section{ACKNOWLEDGEMENTS}

Authors are thankful to the Director of the Institute for providing necessary facilities for conducting the studies. 
Table 4: Shoot and root growth parameters in mango ginger plantlets as influenced by auxin dipping during CEVRH

\begin{tabular}{|l|c|c|c|c|c|}
\hline $\begin{array}{l}\text { Auxin (IBA) } \\
\text { concentration }\end{array}$ & $\begin{array}{c}\text { Shoot Length } \\
\text { (cm) }\end{array}$ & $\begin{array}{c}\text { Collar } \\
\text { thickness (cm) }\end{array}$ & $\begin{array}{c}\text { No. of Primary } \\
\text { roots }\end{array}$ & $\begin{array}{c}\text { Mean root } \\
\text { length (cm) }\end{array}$ & $\begin{array}{c}\text { No. of leaves/ } \\
\text { plantlet }\end{array}$ \\
\hline $0 \mathrm{mg} / \mathrm{L}$ & $4.5 \pm 0.73$ & $0.5 \pm 0.04$ & $4.9 \pm 0.55$ & $3.2 \pm 0.45$ & $5.5 \pm 0.43$ \\
\hline $250 \mathrm{mg} / \mathrm{L}$ & $4.0 \pm 0.46$ & $0.5 \pm 0.04$ & $4.0 \pm 0.57$ & $2.6 \pm 0.21$ & $5.5 \pm 0.71$ \\
\hline $500 \mathrm{mg} / \mathrm{L}$ & $5.0 \pm 0.70$ & $0.5 \pm 0.05$ & $4.8 \pm 0.70$ & $2.6 \pm 0.42$ & $5.6 \pm 0.56$ \\
\hline $1,000 \mathrm{mg} / \mathrm{L}$ & $4.2 \pm 0.61$ & $0.5 \pm 0.03$ & $4.5 \pm 0.43$ & $3.1 \pm 0.20$ & $5.2 \pm 0.70$ \\
\hline
\end{tabular}

Values presented as mean $\pm \mathrm{SE}$.

\section{REFERENCES}

Aggarwal, B.B., Sundaram, C., Malani, N. and Ichikawa, H.2007. Curcumin: the Indian solid gold. Adv. Exp. Med. Biol. 595:1-75.

Bairu, M.W., Stirk, W.A., Dolezal, K. and Staden, J.V. 2008. The role of topolins in micropropagation and somaclonal variation of banana cultivars 'Williams' and 'Grand Naine' (Musa spp. AAA). Plant Cell Tiss. Org. Cult.95:373-379.

Bohra, P., Waman, A.A., Sathyanarayana, B.N. and Umesha, K. 2016. Concurrent ex vitro rooting and hardening in Ney Poovan banana (Musa AB): effect of carbon sources and their interactions. Erwerbs-Obstbau 58:193-198.

Capellades, M., Lemeur, R. and Debergh, P. 1991. Effects of sucrose on starch accumulation and rate of photosynthesis in Rosa cultured in vitro. Plant Cell, Tissue and Organ Culture, 25(1): 21-26.

Elboullani, R., Lagram, K., Al Mousadik, A. and Serghini, M.A. 2017. Effect of explant density and size on the in vitro proliferation and growth of separated shoots of globe artichoke (Cynara cardunculus var. scolymus L.). J. Mat. Environ. Sci.8:2469-2473.

El-Hawaz, R.F., Bridges, W.C. and Adelberg, J.W. 2015. In vitro growth of Curcuma longa $\mathrm{L}$. in response to five mineral elements and plant density in fed-batch culture systems. PLoS One 10:e0118912.

Escalona, M., Cejas, I., Gonzalez-Olmedo, J., Capote, I., Roels, S., Canal, M.J., Rodriguez, R., Sandoval, J. and Debergh, P. 2003. The effect of meta-topolin on plantain propagation using a temporary immersion bioreactor. InfoMusa 12:28-30.

Hutami, S. and Purnamaningsih, R. 2003. Augment clonal Appointment Mangga (Curcuma mangga) through cultured in vitro. Bulletin Plasma Nutfah 9: 39-44.

Leong-Škorničková, J., Otakar, Š. and Karol, M. 2010. Back to types! Towards stability of names in Indian Curcuma L. (Zingiberaceae). Taxon 59:269-282.

Liu, Y.and Nair, M.G. 2012.Curcuma longa and Curcuma mangga leaves exhibit functional food property. Food Chemistry135:634-640.

Lichtenthaler, H. K., Wellburn, A. 1983. Determination of total carotenoids and chlorophylls $a$ and $b$ of leaf extracts in different solvents. Biochem. Soc. Trans. 603: 591-592.

Madhulatha P., Kirubakaran S.I., Sakthivel N. 2006. Effects of carbon sources and auxins on in vitro propagation of banana. Biol. Plant. 50: 782784

Malek, S.N.A., Lee, G.S., Hong, S.L., Yaacob, H., Wahab, N.A., Weber, J.F.and Shah, S.A.A. 2011. Phytochemical and cytotoxic investigations of Curcuma mangga rhizomes. Molecules 16:4539-4548.

Pikulthong, V., Teerakathiti, T., Thamchaipenet, A. and Peyachoknagul, S. 2016. Development of somatic embryos for genetic transformation in Curcuma longa L. and Curcuma mangga Valeton \& Zijp. Agric. Nat. Resour. 50:276285. 
Raihana, R., Faridah, Q.Z., Julia, A.A., Abdelmageed, A.H.A. and Kadir, M. 2011.In vitro culture of Curcuma mangga from rhizome bud. J. Med. Plants Res. 5:6418-6422.

Ranaweera, K.K., Gunasekara, M.T.K. and Eeswara, J.P. 2013. Ex vitro rooting: A low cost micropropagation technique for Tea (Camellia sinensis (L.) O. Kuntz) hybrids. Sci. Hort. 155:8-14.

Salvi, N., George, L. and Eapen, S. 2001. Plant regeneration from leaf base callus of turmeric and random amplified polymorphic DNA analysis of regenerated plants. Plant Cell Tiss. Org. Cult. 66: 113-119.

Sharmin, S.A., Alam, M.J., Sheikh, M.M.I., Zaman, R., Khalekuzzaman, M., Mondal, S.C., Haque, M.A., Alam, M.F. and Alam, I. 2013. Micropropagation and antimicrobial activity of Curcuma aromatica Salisb., a threatened aromatic medicinal plant. Turkish J. Biol. 37:698-708.

Singh, A.K. 2017. Revisiting the status of cultivated plant species agrobiodiversity in India: an overview. Proc. Indian Nat. Sci. Acad. 83:151174.
Sirirugsa, P., Larsen, K. and Maknoi, C.2007.The genus Curcuma L. (Zingiberaceae): distribution and classification with reference to species diversity in Thailand. Gardens' Bull. Singapore 59:203-220.

Suthasinee, S. and Supinya, T. 2019. Antiinûammatory and wound healing eûects of cream containing Curcuma mangga extract. J.Ethnopharmacol.238:111828.

Wahab, I.R.A., Blagojevic, P.D., Radulovic, N.S. and Boylan, F. 2011. Volatiles of Curcuma mangga Val. \& Zijp (Zingiberaceae) from Malaysia. Chem. Biodiv. 8: 2005-2014.

Waman, A.A., Bohra, P. and Aarthi, S. 2018. Propagule size affects yield and quality of Curcuma mangga Val. et Zijp.: An important medicinal spice. Ind. Crops Prod.124: 36-43.

Waman, A.A. and Bohra, P. 2018. Factors governing success in shoot tip culture of bananas with special reference to mixed genomic groups: an overview. Erwerbs-Obstbau 61:9-21.

Woztania A. 2010. Effect of meta-topolin on in vitro propagation of Pelargonium $x$ hortorum and Pelargonium $x$ hederaefolium cultivars. Acta Societatis Botanicorum Poloniae 79: 101-106.

(Received 19.03.2021, Revised on 21.05.2021, Accepted on 19.06.2021) 